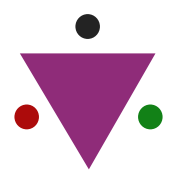

IJCRR

Section: Healthcare

Sci. Journal Impact

Factor: $6.1(2018)$

ICV: 90.90 (2018)

(c) (7) (8)

Copyright@IJCRR

\section{Analysis of Osteocalcin Concentration in Polyarthritic and Systemic Juvenile Idiopatic Arthritis with Combination of Diabetes Mellitus Type 1}

\author{
Tashkent Medical Academy, Tashkent, Uzbekistan \\ Systemic Juvenile Idiopathic Arthritis
}

\section{Alovxon Sulaymanovich Sulaymonov ${ }^{1}$, Dilorom Rakhimjanovna Atayeva', Gulshan Xoldorovna Iskanova ${ }^{1}$, Sayyera Shavkatovna Egamova ${ }^{2}$, Akrom Alovxonovich Sulaymanov ${ }^{3}$, Farrukh Rakhimjanovich Ataev ${ }^{4}$}

'Tashkent Medical Academy, Department of Children's disease №2, Uzbekistan; ${ }^{2}$ Tashkent Medical Academy, Department of Children's disease, Uzbekistan; ${ }^{3 T a s h}$ kent Medical Academy, Department of Forensic Medicine, Uzbekistan; ${ }^{4 W}$ Westminster International University in Tashkent, Uzbekistan.

\title{
ABSTRACT
}

Background \& Aims: Low serum concentrations of the osteocalcin (OC), haemoglobin and osteoporosis is associated polyarthritic and systemic subtypes of the juvenile idiopathic arthritis (PJIA, SJIA) with the combination of type 1 diabetes mellitus (T1DM). We investigated the association of serum OC levels with JIA and the influence of T1DM on this association in participants. Our goal is to study, analyze, and update and introduce new therapeutic techniques into the underlying disease characteristics of chronic rheumatic diseases that are most commonly observed in childhood.

Methods: This study compares concentrations of osteocalcin (OC) between participants with PJIA, SJIA and type 1 diabetes (T1DM) (n=20) and age-, gender- and body mass index (BMI)-matched participants without T1DM ( $n=40)$ among patients with OJIA (oligoarthritic the juvenile idiopathic arthritis), and it explores relationships between OC concentrations JIA and T1DM. Quantitative evaluation of OC was measured in heparin-treated blood plasma by IMMULITE 2000 analyzers. This in vitro study used to monitor mineral metabolism and diagnose osteoporosis. The IMMULITE OC test allows determining only an unfragmented OC molecule, not fragmented ones.

Results: Concentrations of OC were very low in participants with PJIA, SJIA with the combination of T1DM. In OJIA patients without T1DM, concentrations of OC were roughly at normal average. Conclusions: In patients with PJIA and SJIA, lower OC concentrations were related to T1DM.OC was sufficient to predict and prevent osteoporosis in JIA patients with a combination of T1DM. Serum level of OC administered in patients with OJIA without T1DM was in the region of the normal range. No relationship was detected between serum OC levels and OJIA in participants.

Key Words: Juvenile idiopathic arthritis, Type 1 diabetes mellitus, Osteocalcin, Osteoblast-derived protein, Osteoporosis, Hyperglycaemia

\section{INTRODUCTION}

Osteocalcin (OC) also known as bone gamma-carboxy glutamic acid-containing protein (BGLAP), is a noncollagenous protein hormone found in bone and dentin, first identified as a calcium-binding protein in chick bone. ${ }^{1}$ Because $\mathrm{OC}$ has gla domains, its synthesis is vitamin $\mathrm{K}$ dependent.
In humans, OC is encoded by the BGLAP gene. ${ }^{2,3}$ Its receptors include GPRC6A, GPR158, and possibly a third, yet-to-be-identified receptor. ${ }^{4,5} \mathrm{OC}$ is secreted solely by osteoblasts and thought to play a role in the body's metabolic regulation. ${ }^{6}$ In its carboxylated form it binds calcium directly and thus concentrates in bone, but genetic evidence has revealed that it does not play an important role in bone

\section{Corresponding Author:}

Alovxon Sulaymanovich Sulaymonov, Tashkent Medical Academy, Department of Children’s disease №2, Uzbekistan.

ISSN: 2231-2196 (Print)

Received: 20.07 .2020
ISSN: 0975-5241 (Online)

Revised: 12.09 .2020
Accepted: 20.10 .2020
Published: 12.11 .2020 
mineralization. In its uncarboxylated form, $\mathrm{OC}$ acts as a hormone in the body, signalling in the pancreas, fat, muscle, testes, and brain. ${ }^{7}$ In the pancreas, OC acts on beta cells, causing beta cells in the pancreas to release more insulin. ${ }^{8}$ In fat cells, OC triggers the release of the hormone adiponectin, which increases insulin sensitivity. ${ }^{9}$ In muscle, $\mathrm{OC}$ acts on myocytes to promote energy availability and utilization and in this manner favours exercise capacity. ${ }^{10}$ In the testes, OC acts on Leydig cells, stimulating testosterone biosynthesis and therefore affect male fertility. ${ }^{11}$ In the brain, OC plays an important role in development and functioning. ${ }^{12}$ An Acute Stress Response (ASR) (colloquially known as the fight or flight response) stimulates OC to release from bone within minutes in mice, rats, and humans. Injections of high levels of OC alone can trigger an ASR in the presence of adrenal insufficiency. ${ }^{13}$ As OC is produced by osteoblasts, it is often used as a marker for the bone formation process. It has been observed that higher serum OC levels are relatively well correlated with increases in bone mineral density during treatment with anabolic bone formation drugs for osteoporosis, such as teriparatide. In many studies, OC is used as a preliminary biomarker on the effectiveness of a given drug on bone formation. For instance, one study which aimed to study the effectiveness of a glycoprotein called lactoferrin on bone formation used OC as a measure of osteoblast activity. ${ }^{14}$ The demonstration that osteoblasts are endocrine cells stimulating insulin secretion and that this function was fulfilled by $\mathrm{OC}$ came from a classical cell biology experiment. ${ }^{15} \mathrm{OC}$ is carboxylated on three glutamine acid residues within the osteoblasts before being released into the bone extracellular matrix, however, both the carboxylated and uncarboxylated forms of OC can be found in the general circulation. ${ }^{16}$ Since the gamma carboxylase enzyme responsible for this post-translational modification is not expressed in bacteria, the use of recombinant, bacterially produced OC, allowed to address this aspect of OC biology. Recombinant and therefore uncarboxylated $\mathrm{OC}$, but not carboxylated one, was able to induce Insulin expression in pancreatic islets thus indicating that it is the uncarboxylated form of OC that is acting as a hormone. ${ }^{17,18} \mathrm{OC}$ circulates physiologically in several carboxylation states, two of which are reliably quantifiable in humans..$^{19} \mathrm{OC}$ is synthesized by osteoblasts and is posttranslationally g- carboxylated on three Gla residues in a vitamin K-dependent manner to carboxylated OC (cOCN). It is thought carboxylated osteocalcin $(\mathrm{cOCN})$ has effects on bone mineralization and bone turnover while attached to calcium in bone..$^{20,21}$ Clinically, lower circulating concentrations have been associated with insulin resistance, suggesting the need to evaluate these relationships in people both with and without T1DM, T2DM. ${ }^{22,23}$ The number of all people who currently have SJIA is estimated to be between 5 and 15 people in every $100,000 \cdot{ }^{24-26} \mathrm{OC}$ also known as Bone Gla Protein is a non-collagenous, 49 amino acid long single-chain protein (MW $5.8 \mathrm{kDa}$ ), containing three $\gamma$-carboxyglutamic acids. ${ }^{27-30} \mathrm{It}$ is secreted solely by osteoblasts and its biosynthesis is vitamin $\mathrm{K}$ dependent. ${ }^{31,32}$ During bone formation, newly synthesized OC is incorporated into the bone matrix, and a small fraction is secreted directly into the circulation, but its function remains elusive. Circulating OC concentrations have been broadly used for evaluating the rate of bone turnover in metabolic bone diseases such as hyperparathyroidism, Paget's disease and renal osteodystrophy. ${ }^{33-36}$

The term 'juvenile idiopathic arthritis' has been adopted as an umbrella term to indicate disease of childhood-onset (arbitrarily before the 16th birthday) characterised primarily by arthritis persisting for at least 6 weeks and currently has no known cause. ${ }^{37}$ The circulating level of OC (10-25\%) reflects the rate of bone formation. In juvenile idiopathic arthritis (JIA), a decrease in bone mass has been described in a high percentage of children with increased risk of osteoporosis. ${ }^{38}$ This study aimed to explore the early changes in the predictors of bone turnover (OC) in children with JIA, without clinical symptoms and/or radiological signs of osteoporotic fractures.

\section{MATERIALS AND METHODS}

\section{Study design and study subjects}

This retrospective study included sixty patients with SJIA (40 girls and 20 boys) according to the International League of Associations for Rheumatology (ILAR) criteria ${ }^{28}$ and was consecutively selected from Rheumatology, Rehabilitation and Endocrine Department, Tashkent Medical Academy, for the study. Twenty participants withT1DM were matched 2:1 for age, gender and BMI category to 40 who did not have of type 1 diabetes mellitus (T1DM). All participants had SJIA. Identification of participants with diagnosed T1DM ( $\mathrm{HbA1c}$ $>6.3 \%, \mathrm{FBG}>6.5 \mathrm{mmol} / \mathrm{L}$ ) was completed through clinical chart review. Those in the non-T1DM group did not have a clinical diagnosis of T1DM, use any antidiabetic medications, or have an $\mathrm{HbAlc}$ over $6.3 \%$. Any participants with acute medical illnesses, neurodegenerative or neuropsychiatric diagnoses, active cancer, bone disease were excluded. Participants were screened using the standardized MiniMental State Exam (sMMSE) to exclude those with cognitive impairment; those with scores of less than 24 were excluded. ${ }^{27}$ The disease duration ranged from 2 months to 5.2 years. Children excluded from the study were those older than 16 years and younger than 4 years, Children with any clinical or radiological finding of osteoporosis, with secondary causes of low bone mass, such as a clinical history of rickets, hypoparathyroidism, hyperthyroidism or hypothyroidism, poor gastrointestinal absorption, and renal or hepatic insufficiency. 


\section{Demographics and Clinical Characteristics}

Demographic and clinical characteristics of the study group both at the time of enrolment and at follow-up are described in Table 1. Sociodemographic, clinical and anthropometric data for patients and controls were obtained through complete medical history, physical, medicational and articular examinations. Articular Disease Severity Score (ADSS) ${ }^{48,49}$ were obtained from all patients. The joint index used was the whole 71 joint count. ${ }^{50}$ The number of arthritis and systemic inflammation response was recorded through complete medical history, physical and articular examinations. Anthropometric data including weight, height, and BMI, were collected from medical records. Body fat percentage was measured by bioelectric impendence ${ }^{29}$ Insulin was measured using an enzyme-linked immunosorbent assay (ELISA; ab200011 DeFactum, Tashkent, Uzbekistan) and glucose was measured using a standard glucometer (DeFactum, Tashkent, Uzbekistan). Homeostatic model of insulin resistance (HOMAIR) was calculated using the formula: [fasting insulin (micro $\mu / \mathrm{L}) \mathrm{x}$ fasting glucose $(\mathrm{nmol} / \mathrm{L})] / 22.5^{30} \mathrm{HbA} 1 \mathrm{c}$, cholesterol and triglycerides were assessed by standard lab testing at Sunnybrook Health Sciences Centre.

\section{Osteocalcin Measurements}

This study measured OC. Fasting blood was drawn $(0900 \mathrm{~h} \pm$ 30 mins) and collected blood samples were centrifuged at $4^{\circ}$ $\mathrm{C}, 1000 \mathrm{rpm}$ for 10 minutes. Serum was separated and stored at $-80^{\circ} \mathrm{C}$ until assayed. Serum concentrations of OC were quantified by ELISA (Immulite 2000).

\section{Statistical Analyses}

Differences between groups with and without T1DM were tested with independent samples t-tests. To explore potential confounders, participant characteristics were compared between those with T1DM and those without using an independent samples t-test for continuous measures or a chisquared test for categorical measures, and relationships between participant characteristics and serum OC measures were assessed using non-parametric tests (Spearman's rho or Mann-Whitney U tests) because they are less sensitive to possible outlier effects in small sample sizes. Potential confounders thus identified were included in analyses of covariance (ANCOVA) to test the independent effect of T1DM on serum OC concentrations. Differences between study groups were evaluated by Student's $t$-test for normally or MannWhitney $U$ test for non-normally distributed variables, and chi-squared statistic for proportions. McNemar for parametric and the Wilcoxon signed-rank test on nonparametric were used to comparing the baseline. For all statistical testing, two-sided probability values were reported and statistical significance was established at $P<0.05$. We explored relationships between OC types and clinical characteristics in subgroups with and without T1DM using non-parametric tests. Post-hoc models were run in subgroups not using an insulin preparation. We assessed interactions between T1DM and participant characteristics in predicting OC concentrations as interaction terms in ANCOVA models.

\section{RESULST}

\section{Participant characteristics}

Characteristics of the 20 participants with T1DM and of the 40 without T1DM are reported in Table 1. Participants with T1DM had significantly different metabolic, fitness and lipid profiles compared to participants without T1DM (Table 1)

Table 1: Baseline characteristics of study participants

\begin{tabular}{lccc} 
Characteristics & $\begin{array}{c}\text { PJIA } \\
\text { orSJIA+T1DM } \\
(\mathbf{n}=\mathbf{2 0})\end{array}$ & $\begin{array}{c}\text { JIA without } \\
\text { TiDM }(\mathbf{n = 4 0})\end{array}$ & $\mathbf{p}$ \\
Age (y) & $8.12 \pm 3.2$ & $8.0 \pm 3.1$ & $<0.001$ \\
BMI $\left(\mathrm{kg} / \mathrm{m}^{2}\right)$ & $20.6 \pm 3.1$ & $21.1 \pm 3.4$ & 0.027 \\
Height $(\mathrm{cm})$ & $125.2 \pm 4.3$ & $128 \pm 3.9$ & $<0.001$ \\
$\begin{array}{l}\text { Fasting glucose } \\
\text { (mmol/L) }\end{array}$ & $6.96 \pm 1.42$ & $4.85 \pm 1.2$ & 0.005 \\
$\begin{array}{l}\text { Fasting insulin } \\
\text { (pmol/L) }\end{array}$ & $169.8 \pm 66.2$ & $133.5 \pm 32.43$ & $<0.01$ \\
must be $<174$ & & & \\
pmol/L & & & \\
HOMA-IR & $8.8 \pm 0.7$ & $4.8 \pm 0.1$ & 0.03 \\
HbAic $(\%)$ & $7.12 \pm 0.89$ & $6.01 \pm 1.83$ & $<0.01$ \\
\hline
\end{tabular}

\section{Correlation of $\mathrm{OC}$ and disease state}

OC levels were lower in the active than in the inactive phase, but without statistical significance $\mathrm{P}=0.135$. Baseline characteristics and BMD measurements of the study participants $(\mathrm{n}=60)$ (Fig. 1).

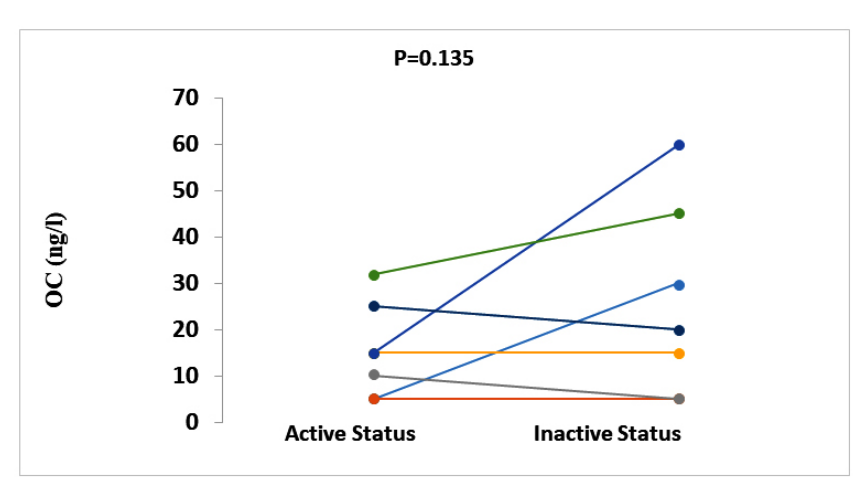

\section{Patient characteristic with respect to BMI and BMD}

The Body Mass Index (BMI) and Bone Mineral Density (BMD) measurements at spine and femur were significantly 
different between T1DM $(\mathrm{n}=20)$ and No T1DM $(\mathrm{n}=40)$ patients (Table 2). The clinical picture in patients with active phase of SJIA is represented in Table 3.

Table 2

\begin{tabular}{|c|c|c|c|}
\hline Parameters & $\begin{array}{c}\text { PJIA, } \\
\begin{array}{c}\text { SJIA+T1DM (n } \\
=\mathbf{2 0})\end{array}\end{array}$ & $\begin{array}{c}\text { JIA without } \\
\text { T1DM }(n= \\
40)\end{array}$ & p value \\
\hline Age (Years) & $8.12 \pm 3.2$ & $8.0 \pm 3.1$ & 0.999 \\
\hline BMI $\left(\mathrm{Kg} / \mathrm{m}^{2}\right)$ & $16.5 \pm 2.5$ & $14.5 \pm 2.5$ & $<0.001$ \\
\hline $\begin{array}{l}\text { Spine BMD (g/ } \\
\left.\mathrm{cm}^{2}\right) \\
\text { T Score }\end{array}$ & $\begin{array}{c}0.884 \pm 0.17 \\
-1.91 \pm 1.61\end{array}$ & $\begin{array}{l}1.087 \pm 0.14 \\
-0.46 \pm 1.33\end{array}$ & $<0.0001$ \\
\hline $\begin{array}{l}\text { Femur BMD (g/ } \\
\left.\mathrm{cm}^{2}\right) \\
\text { T Score }\end{array}$ & $\begin{array}{l}0.778 \pm 0.11 \\
-1.28 \pm 1.17\end{array}$ & $\begin{array}{l}0.936 \pm 0.12 \\
-0.32 \pm 1.06\end{array}$ & 0.0002 \\
\hline Calcium (mg/dL) & $8.21 \pm 1.86$ & $8.89 \pm 1.23$ & 0.89 \\
\hline $\begin{array}{l}\text { Phosphorous } \\
\text { (mg/dL) }\end{array}$ & $5.89 \pm 1.49$ & $5.12 \pm 1.89$ & 0.71 \\
\hline OC (ng/mL) & $10.83 \pm 2.1$ & $17 \cdot 71 \pm 2.44$ & $<0.0001$ \\
\hline
\end{tabular}

Table 3

Indicators $\begin{aligned} & \text { The number of patients partici- } \\ & \text { pated in clinical research }(\mathbf{n}=60)\end{aligned}$
PJIA or $\quad$ JIA without T1DM
SJIA+T1DM $\quad(n=40)$
$(n=20)$$\quad \%$

Articular manifestations

$\begin{array}{lll}\text { Narrow joint spaces } & 80,9 \% & 12,5 \% \\ \text { New bone formation } & 56,4 \% & 14,9 \% \\ \begin{array}{l}\text { Juxta articular osteo- } \\ \text { penia }\end{array} & 68,9 \% & 26,2 \% \\ \begin{array}{l}\text { Morning stiffness } \\ \text { Tenosynovitis }\end{array} & 98,2 \% & 56,9 \% \\ \begin{array}{l}\text { Synovial membrane } \\ \text { proliferation and thick- }\end{array} & 86.9 \% & 36.6 \% \\ \text { ening } & & \\ \begin{array}{l}\text { Periarticular soft tissue } \\ \text { swelling }\end{array} & 89.7 \% & 46.6 \% \\ \begin{array}{l}\text { Swollen joints } \\ \text { Disability index }\end{array} & 85,7 \% & 63,2 \% \\ \text { Arthralgia } & 98,7 \% \text { (high) } & 12,5 \% \text { (high) } \\ \text { Arthritis that involves } & 12,8 \% & 25,2 \% \\ \text { S } 4 \text { joints } & 79,8 \% & 89,9 \% \\ \begin{array}{l}\text { Deformities } \\ \text { Erosion }\end{array} & 59,8 \% & 11.3 \% \\ \text { Limitation of range of } & 88.5 \% & 8.3 \% \\ \text { motion } & 89,8 \% & 21.3 \% \\ \text { Tenderness of joints } & 78.9 \% & 12.6 \% \\ \text { Joint contractures } & 86.3 \% & 36.9 \%\end{array}$

Increased heat in one $\quad 86.6 \% \quad 23.6 \%$ or more joints in all subtypes

\section{Extra-articular manifestations}

Anaemia

Fatigue

$92.6 \%$

$33.5 \%$

Lethargy

$76.8 \%$

$23.4 \%$

Thrombocytosis

$82.3 \%$

$26.5 \%$

Increased ESR

$26.1 \%$

$2.6 \%$

Lymphadenopathy

$69.8 \%$

$23.2 \%$

(generalized)

Hepatosplenomegaly

$26.4 \%$

$4.9 \%$

Serositis

$42.3 \%$

$12.1 \%$

Hepatitis

$59.6 \%$

$26.3 \%$

Fever (spikes once or

$65.3 \%$

$36.3 \%$

twice daily)

Salmon-pink rash

$84.2 \%$

$21.4 \%$

Soft tissue swelling

$66.9 \%$

$26.1 \%$

Pericarditis

$56.8 \%$

$22.1 \%$

Pleuritis

Anterior uveitis

Low body height

Poor appetite

$26.8 \%$

$3.9 \%$

$33.2 \%$

$4.1 \%$

$69.2 \%$

$13.4 \%$

$13.5 \%$

$5.3 \%$

Reduced physical

activity

$76.8 \%$

$26.4 \%$

$59.8 \%$

$12.8 \%$

\begin{tabular}{lll} 
Limping & $86.9 \%$ & $26.3 \%$ \\
Flu-like symptoms & $56.3 \%$ & $26.2 \%$ \\
\hline
\end{tabular}

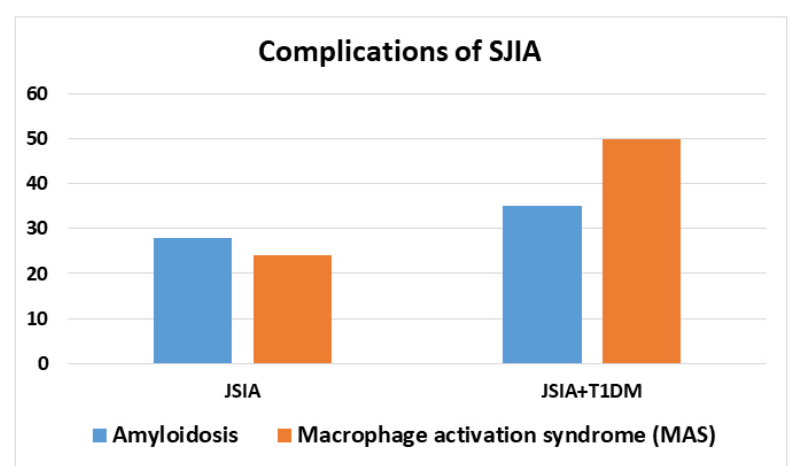

Diagram 2

Table 4

\begin{tabular}{lccc} 
Variables JIA & $\begin{array}{c}\text { PJIA or SJIA+T1DM } \\
(\mathbf{n}=\mathbf{2 0})\end{array}$ & $\begin{array}{c}\text { JIA without } \\
\text { TiDM } \\
(\mathbf{n}=\mathbf{4 0})\end{array}$ & $\begin{array}{c}\mathbf{p} \\
\text { value }\end{array}$ \\
Serum laboratory & & & \\
$\mathrm{Ca}(\mathrm{mg} / \mathrm{dl})$ & $8.87 \pm 0.54$ & $9.07 \pm 1.44$ & 0.3 \\
$\mathrm{Ph}(\mathrm{mg})$ & $5 \pm 1.63$ & $4.8 \pm .89$ & 0.6 \\
ALP $(\mathrm{U} / \mathrm{l})$ & $149.52 \pm 72$ & $200.08 \pm 74.39$ & 0.001 \\
OC $(\mathrm{ng} / \mathrm{ml})$ & $1.20 \pm 0.94$ & $4.01 \pm 1.32$ & 0.4 \\
\hline
\end{tabular}


Table 5: Ca: total calcium, Ph: phosphorus, ALP: alkaline phosphatase, OC: Osteocalcin

$\begin{array}{lcc}\text { Characteristics, no. } & \text { PJIA or SJIA+T1DM } & \text { JIA patients } \\ (\%) \text { or mean } \pm \text { SD } & \text { patients }(20) & \text { without } \\ & & \text { TiDM }(40)\end{array}$

\section{Disease subtype}

Oligoarthritis

Polyarthritis

Systemic
9

6

5
18

13

9
COURSES OF SYSTEMIC JUVENILE IDIOPATHIC ARTHRITIS (SJIA)

anonocyclic $\backsim$ Policyclic $\equiv$ Persistent

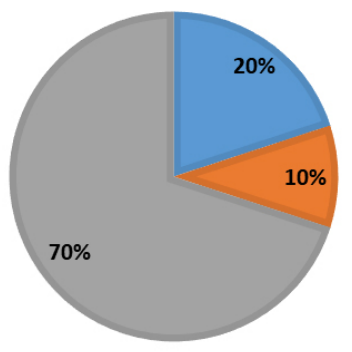

Diagram 3

Table 6: Densitometry of patients

\begin{tabular}{lcccccc}
$\begin{array}{l}\text { Disease } \\
\text { Densito } \\
\text { metry manifestations }\end{array}$ & T1DM & OJIA & PJIA & SJIA & T1DM+ PJIA & TiDM+SJIA \\
normal bone mineral density & $98 \%$ & $96 \%$ & $84 \%$ & $76 \%$ & $60 \%$ & $50 \%$ \\
low bone mass (osteopenia) & $2 \%$ & $4 \%$ & $5 \%$ & $20 \%$ & $20 \%$ & $25 \%$ \\
osteoporosis & $1 \%$ & $1 \%$ & $1 \%$ & $4 \%$ & $20 \%$ & $25 \%$ \\
\hline
\end{tabular}

Table 7: Densitometry of patients

\begin{tabular}{|c|c|c|c|c|c|c|}
\hline $\begin{array}{l}\text { Disease } \\
\text { Medicines }\end{array}$ & T1DM & OJIA & PJIA & SJIA & TiDM+ PJIA & TiDM+SJIA \\
\hline $\begin{array}{l}\text { Glucocorticoid (Prednisoloneoral, intravenous, } \\
\text { intra-articular) }\end{array}$ & $18 \%$ & $26 \%$ & $84 \%$ & $96 \%$ & $70 \%$ & $80 \%$ \\
\hline TNF alpha blockers (Etanercept) & $5 \%$ & $59 \%$ & $86 \%$ & $30 \%$ & $72 \%$ & $36 \%$ \\
\hline Anti- interleukin- 6 agents (Tocilizumab) & $6 \%$ & $67 \%$ & $86 \%$ & $56 \%$ & $46 \%$ & $56 \%$ \\
\hline Anti-interleukin-ı agents (Anakinra) & $8 \%$ & $76 \%$ & $84 \%$ & $50 \%$ & $56 \%$ & $60 \%$ \\
\hline T-cell regulatory agents (Abatacept) & $6 \%$ & $59 \%$ & $86 \%$ & $52 \%$ & $65 \%$ & $60 \%$ \\
\hline $\begin{array}{l}\text { Disease-modifying antirheumatic drug (Meto- } \\
\text { threxate) }\end{array}$ & $2 \%$ & $64 \%$ & $85 \%$ & $90 \%$ & $70 \%$ & $75 \%$ \\
\hline NSAIDS (Ibuprofen per oral or topical) & $11 \%$ & $65 \%$ & $81 \%$ & $84 \%$ & $80 \%$ & $85 \%$ \\
\hline Insulin (subcutaneous) & $98 \%$ & o\% & o\% & o\% & $98 \%$ & $95 \%$ \\
\hline Antibiotics (Ceftriaxone) & $42 \%$ & $40 \%$ & $55 \%$ & $60 \%$ & $80 \%$ & $85 \%$ \\
\hline $\begin{array}{l}\text { Betamethasone dipropionate and betametha- } \\
\text { sone sodium phosphate (Diprospan subcutane- } \\
\text { ous) }\end{array}$ & $25 \%$ & $35 \%$ & $75 \%$ & $84 \%$ & $60 \%$ & $85 \%$ \\
\hline Enzyme drug (Pancreatin) & $78 \%$ & $6 \%$ & $24 \%$ & $46 \%$ & $60 \%$ & $70 \%$ \\
\hline Cristalloid (Combisol or Reosorbilact) & $12 \%$ & $15 \%$ & $45 \%$ & $70 \%$ & $80 \%$ & $95 \%$ \\
\hline $\begin{array}{l}\text { Methylxanthine phosphodiesterase inhibitor } \\
\text { (Trental) }\end{array}$ & $11 \%$ & $21 \%$ & $61 \%$ & $84 \%$ & $70 \%$ & $85 \%$ \\
\hline Ferrum III component drug (Maltofer) & $12 \%$ & $15 \%$ & $45 \%$ & $60 \%$ & $70 \%$ & $75 \%$ \\
\hline
\end{tabular}

Table 8: Skeletomuscular functional insufficiency

\begin{tabular}{lccc}
$\begin{array}{l}\text { Degree } \\
\text { Disease }\end{array}$ & $\begin{array}{c}\text { Skeletomuscular functional } \\
\text { insufficiency I degree }\end{array}$ & $\begin{array}{c}\text { Skeletomuscular functional } \\
\text { insufficiency II degree }\end{array}$ & $\begin{array}{c}\text { Skeletomuscular functional } \\
\text { insufficiency III degree }\end{array}$ \\
T1DM & $11 \%$ & $41 \%$ & $71 \%$ \\
OJIA & $21 \%$ & $51 \%$ & $12 \%$ \\
PJIA & $12 \%$ & $45 \%$ & $21 \%$ \\
SJIA & $84 \%$ & $90 \%$ & $70 \%$ \\
T1DM+ PJIA & $60 \%$ & $91 \%$ & $70 \%$ \\
T1DM+SJIA & $84 \%$ & $90 \%$ & $70 \%$ \\
\hline
\end{tabular}


Table 9: Effect of medical conditions on circulating osteocalcin concentration

\begin{tabular}{|c|c|c|}
\hline Condition & $\begin{array}{l}\text { Effect on circulating } \\
\text { osteocalcin }\end{array}$ & Other information \\
\hline $\mathrm{T} 1 \mathrm{DM}$ & Decrease & Correlates with disease stage and adequate insulin therapy \\
\hline OJIA & No change & There is no need to specific therapy \\
\hline PJIA & No change (15\%) & $\begin{array}{l}\text { Correlates with adequate hormonetherapy, rehabilitation with antiosteoporo- } \\
\text { sis drugs and vit K supplementation }\end{array}$ \\
\hline SJIA & Decrease & $\begin{array}{l}\text { Correlates with adequate hormonetherapy, rehabilitation with antiosteoporo- } \\
\text { sis drugs and vit K supplementation }\end{array}$ \\
\hline TiDM+ PJIA & Decrease & $\begin{array}{l}\text { Correlates with adequate hormonetherapy, rehabilitation with antiosteoporo- } \\
\text { sis drugs and vit K supplementation }\end{array}$ \\
\hline TiDM+SJIA & Decrease & $\begin{array}{l}\text { Correlates with adequate hormonetherapy, rehabilitation with antiosteoporo- } \\
\text { sis drugs and vit K supplementation }\end{array}$ \\
\hline
\end{tabular}

\section{Prednisone dose}

All participants are followed over five years of rehabilitation. Bone mass index is measured with dual-energy x-ray absorptiometry (DEXA) at the beginning of the study, at the middle of the five years, and the end of five years. New diagnoses of osteoporosis and osteoporotic fractures are recorded during this time and the following graph is plotted based on the data recorded (Table 2- Table7).

\section{DISCUSSION}

Juvenile idiopathic arthritis is an HLA-associated synovial inflammation that can cause arthralgias/arthritis in children. In this study, we evaluated levels of OC as indicators of SJIA activity. We found that: (1) Reduced OC levels have been found in children with chronic rheumatic diseases, (2) children with SJIA who have an improvement in their disease activity have an improvement in bone mineral density, heralded by an increase in serum OC values, (3) serum OC levels were lower in the active phase than in the inactive phase of SJIA (Table 8, 9), (4) The degree of anaemia and microcytosis was directly related to JRA activity and the most severe anaemia was seen in patients with active systemic JIA (Fig 1-4), (5) Osteoporosis is characterized by loss of bone mass associated with increased fragility and risk of fractures. ${ }^{39}$ It is diagnosed by measuring a real bone mineral density (BMD, $\mathrm{g} / \mathrm{cm} 2) \cdot{ }^{44}$ It is important to detect the early changes of bone mass in JIA to identify patients at risk to develop reduced bone mass and osteoporotic fracture. ${ }^{40}$ Biochemical markers of bone turnover are indirect indices of skeletal metabolism. A range of biochemical markers have been investigated for applicability to determine bone health in children with JIA. ${ }^{41}$ $\mathrm{OC}(\mathrm{OC})$ is the major non -collagenous protein of the bone matrix. OC is predominantly synthesized by mature osteoblasts and is mainly incorporated into the bone matrix. The circulating level of OC (10-25\%) reflects the rate of bone formation..$^{42}$ Deoxypyridinoline (DPD) is one of two major cross-links in the collagen molecule. It is excreted in the urine and is considered a bone-specific resorption marker ${ }^{43}$ JIA strongly affects the skeletal system in certain patients, which may lead to either localized or generalized osteoporosis. $^{44}$

There are relatively few deaths from osteoporosis observed in pediatric younger people, i.e., in the younger group of people we have identified; however, it creates the most conducive environment for disease due to pain, regular exercise interference, risk of fracture, and long-term outcomes. This is in agreement with previous studies wgo reported that the serum level of OC was significantly lower in JIA patients compared to healthy control. ${ }^{45-47}$ We demonstrated that there was a significant decrease in the serum level of OC in patients with SJIA and T1DM compared to control group.Several studies in the literature demonstrated that chronic inflammatory processes result in generalized bone-mass loss, bone demineralization, and progressive radiological abnormalities. The bone articular complications consist of juxta-articular osteopenia, subchondral and marginal bone erosions. ${ }^{48}$ Discovered that osteocalcin serum test maintained to detect the level of osteoporosis of JIA with combination T1DM. Throughout the research performed the blood test on 60 patients. Of the 20 patients with the JIA+T1DM, 18 had positive test results and 2 had negative test results. Of the 40 patients without the T1DM, 8 had positive test results. Test sensitivity is $18 / 18+2=0.9$ or $90 \%$ for patients with diseases. Test specificity is $32 / 32+8=0.8$ or $80 \%$. Sensitivity and specificity are determined by test parameters and are thus intrinsic to the text itself.osteocalcin acts as a hormone to affect insulin sensitivity and energy expenditure; only the undercarboxylated form of osteocalcin is active.

\section{CONCLUSION}

Key aspects of OC measurement are activities aimed at eliminating these active diseases, normalizing joint function, normal development, and preventing joint injuries using adequate therapy. 


\section{ACKNOWLEDGMENT}

Authors acknowledge the immense help received from the scholars whose articles are cited and included in references to this manuscript. The authors are also grateful to authors / editors / publishers of all those articles, journals, and books from which the literature for this article has been reviewed and discussed.

\section{Conflict of Interest: Nil}

\section{Source of Funding: Nil}

\section{REFERENCES}

1. Hauschka PV, Reid ML. Timed appearance of a calcium-binding protein-containing gamma-carboxyglutamic acid in developing chick bone. Dev Bio1978;65 (2): 426-34.

2. Puchacz E, Lian JB, Stein GS, Wozney J, Huebner K, Croce C. Chromosomal localization of the human OC gene. Endocrinology 1989;124 (5): 2648-50.

3. Cancela L, Hsieh CL, Francke U, Price PA. Molecular structure, chromosome assignment, and promoter organization of the human matrix Gla protein gene. J Bio Chem 1990; 265 (25): 15040-8..

4. Pi M, Wu Y, Quarles LD. GPRC6A mediates responses to $\mathrm{OC}$ in $\beta$-cells in vitro and pancreas in vivo. $\mathrm{J}$ Bone Miner Res 2011;26 (7):1680-3.

5. Berger JM, Singh P, Khrimian L, Morgan DA, Chowdhury S, Arteaga-Solis E, et al. Mediation of the Acute Stress Response by the Skeleton. Cell Metab 2019;30(5):890-902.e8.

6. Lee NK, Sowa H, Hinoi E, Ferron M, Ahn JD, Confavreux C, et al. Endocrine regulation of energy metabolism by the skeleton. Cell. 2007;130 (3):456-69.

7. Karsenty G, Olson EN. Bone and Muscle Endocrine Functions: Unexpected Paradigms of Inter-organ Communication. Cell 2016; 164 (6): 1248-1256.

8. Lee NK, Sowa H, Hinoi E, Ferron M, Ahn JD, Confavreux C, et al. Endocrine regulation of energy metabolism by the skeleton. Cell 2007;130 (3): 456-69.

9. Lee NK, Sowa H, Hinoi E, Ferron M, Ahn JD, Confavreux C, et al. Endocrine regulation of energy metabolism by the skeleton. Cell. 2007; 130 (3): 456-69.

10. Mera P, Laue K, Ferron M, Confavreux C, Wei J, Galán-Díez $\mathrm{M}$, et al. OC Signaling in Myofibers Is Necessary and Sufficient for Optimum Adaptation to Exercise. Cell Metabolism. 2016; 23 (6): 1078-1092.

11. Karsenty G, Oury F "Regulation of male fertility by the bonederived hormone OC". Mol Cel Endocrinol 2014;382 (1): 521526.

12. Obri A, Khrimian L, Karsenty G, Oury F. OC in the brain: from embryonic development to age-related decline in cognition. Nat Rev Endocrinol 2018;14 (3): 174-182.

13. Meyer-Berger J, Singh P, Khrimian L, Morgan D, Chowdhury S, Arteaga-Solis E, et al. Mediation of the Acute Stress Response by the Skeleton. Cell Metab 2019;30(5):890-902.e8

14. Bharadwaj S, Naidu AG, Betageri GV, Prasadarao NV, Naidu AS. Milk ribonuclease-enriched lactoferrin induces positive effects on bone turnover markers in postmenopausal women. Osteoporosis International. 2009; 20 (9): 1603-11.

15. Lee NK, Sowa H, Hinoi E, Ferron M, Ahn JD, Confavreux C, et al. Endocrine regulation of energy metabolism by the skeleton. Cell. 2007; 130(3):456-69.
16. Poser JW, Esch FS, Ling NC, Price PA. Isolation and sequence of the vitamin K-dependent protein from human bone. Undercarboxylation of the first glutamic acid residue. J Biol Chem. 1980; 255(18):8685-91.

17. Ferron M, Hinoi E, Karsenty G, Ducy P. OC differentially regulates beta cell and adipocyte gene expression and affects the development of metabolic diseases in wild-type mice. Proc Natl Acad Sci U S A. 2008; 105(13):5266-70.

18. Bonneau J, Ferland G, Karelis AD, et al. Association between OC gamma-carboxylation and insulin resistance in overweight and obese postmenopausal women. J Diabetes Complications. 2017;31(6):1027-1034. DOI:10.1016/j.jdiacomp.2017.01.023.

19. Lee NK, Sowa H, Hinoi E, et al. Endocrine Regulation of Energy Metabolism by the Skeleton. Cell. 2007;130(3):456-469.

20. Hauschka PV. OC: the vitamin K-dependent Ca2+-binding protein of bone matrix. Haemostasis. 1986;16(3-4):258-272.

21. Shea MK, Gundberg CM, Meigs JB, et al. $\gamma$-carboxylation of $\mathrm{OC}$ and insulin resistance in older men and women. Am J Clin Nutr 2009;90(5):1230-1235.

22. Hwang YC, Jeong IK, Ahn KJ, Chung HY. The uncarboxylated form of $\mathrm{OC}$ is associated with improved glucose tolerance and enhanced beta-cell function in middle-aged male subjects. Diabetes Metab Res Rev 2009;25(8):768-772.

23. Ramanan AV, Grom AA. Rheumatology (Oxford) 2005;44(11):1350-3.

24. Beukelman T, Patkar NM, Saag KG, et al. 2011 American College of Rheumatology recommendations for the treatment of juvenile idiopathic arthritis: initiation and safety monitoring of therapeutic agents for the treatment of arthritis and systemic features. Arthritis Care Res 2011;63(4):465-482.

25. Dewitt EM, Kimura Y, Beukelman T, et al. Consensus Treatment Plans for New-Onset Systemic Juvenile Idiopathic Arthritis. Arthritis Care Res 2012;64(7):1001-1010.

26. Folstein MF, Folstein SE, McHugh PR. Mini-mental state. A practical method for grading the cognitive state of patients for the clinician. J Psychiatr Res. 1975;12(3):189- 198.

27. Petty RE, Southwood TR, Manners P, Baum J, Glass DN, Goldenberg J, et al. International League of Associations for Rheumatology classification of juvenile idiopathic arthritis: second revision, Edmonton, 2001. J Rheumatol 2004;31:390-2.

28. Forhan M, Zagorski BM, Marzonlini S, Oh P, Alter DA. Predicting Exercise Adherence for Patients with Obesity and Diabetes Referred to a Cardiac Rehabilitation and Secondary Prevention Program. Can J Diabetes. 2013;37(3):189-194.

29. Matthews DR, Hosker JP, Rudenski AS, et al. Homeostasis model assessment: insulin resistance and fl-cell function from fasting plasma glucose and insulin concentrations in man. Diabetologia. 1985:412-419.

30. Gundberg CM, Hauschka PV, Lian JB, Gallop PM. OC: Isolation, characterization, and detection, Method Enzymol 1984; 107: 516-544.

31. Gundberg CM, Lian JB, Booth SL. Vitamin K-dependent carboxylation of OC: friend or foe? Adv Nutr 2012; 3 (2): 149-157.

32. Ljunghall S,Hallgren R, Rastad J. Serum OC levels in normal subjects and patients with primary hyperparathyroidism, Exp. Clin. Endocrinol. 1985;86(2);218-222.

33. Papapoulos SE, Frolich M, Mudde AH, Serum OC in Paget's disease of bone: basal concentrations and response to bisphosphonate treatment. J Clin Endocrinol Metab 1987;65(1):89-94.

34. Amado JA, Riancho JA, De Francisco AL, Cotorruelo JG, Feijanes J, Arias M, et al., Hyperparathyroidism is responsible for the increased levels of OC in patients with normally functioning kidney grafts, Nephron 1989; 52(3): 209-215. 
35. Delmas PD, Wilson DM, Mann KG, Riggs BL, Effect of renal function on plasma levels of bone Gla-protein. J Clin Endocrinol Metab 1983;57(5):1028-1030.

36. Petty RE, Sorthwood TR, Baum J et al. Revision of the proposed classification criteria for juvenile idiopathic arthritis: Durban. J Rheumatol 1998;25:1991-1994.

37. Reed A, Haugen M, Pachman LM, Langman CB. Abnormalities in serum $\mathrm{OC}$ values in children with chronic rheumatic diseases. J Pediatr 1990;116:574-80.

38. Reed AM, Haugen M, Pachman LM, Langman CB. Repair of osteopenia in children with juvenile rheumatoid arthritis. J Pediatr 1993;122:693-6.

39. Hussein A, Stein J, Ehrich JHH: C-reactive protein in the assessment of disease activity in juvenile rheumatoid arthritis and juvenile spondyloarthritis. Scand J Rheumatol 1987;16:101-5.

40. Kirel B, Yetgin S, Saatci U, Ozen S, Bakkaloglu A, Besbas N. Anaemia in juvenile chronic arthritis. Clin Rheumatol 1996;15:236-41.

41. Roth J, Bechtold S, Borte G, Dressler F, Hermann JG, Borte M. Osteoporosis in juvenile idiopathic arthritis - a practical approach to diagnosis and therapy. Eur J Pediatr 2007;166: 775-84.

42. Celiker R, Bal S, Bakkaloglu A, Ozaydin E, Coskun T, Cetin $\mathrm{A}$, et al. Factors playing a role in the development of decreased bone mineral density in juvenile chronic arthritis. Rheumatol Int 2003;23:27-129.

43. Stagi S, Masi L, Capannini S, Cimaz R, Tonini G, MatucciCerinic $\mathrm{M}$, et al. Cross-sectional and longitudinal evaluation of bone mass in children and young adults with juvenile idiopathic arthritis: the role of bone mass determinants in a large cohort of patients. J Rheumatol 2010;37:1935-43.

44. Brik R, Keidar Z, Schapira D, Israel O. Bone mineral density and turnover in children with systemic juvenile chronic arthritis. J Rheumatol 1998;25:990-2.

45. Falcini F, Ermini M, Bagnoli F. Bone turnover is reduced in children with juvenile rheumatoid arthritis. J Endocrinol Invest 1998;21:31-6.

46. Kandil ME, Mourad A, El-Hamshary A, Hussein G, Ahmed A, Abdel-Mawgoud S. Evaluation of bone mineral density and bone turnover markers in Egyptian children with juvenile rheumatoid arthritis. Arch Med Sci 2009;5:434-42.

47. Mason T, Reed AM, Nelson AM, Thomas KB, Patton A, Hoffman $\mathrm{AD}$, et al. Frequency of abnormal hand and wrist radiographs at the time of diagnosis of polyarticular juvenile rheumatoid arthritis. J Rheumatol 29:2214-2218. 